E. S. Buyanova ${ }^{1}$, Yu.V. Emelyanova ${ }^{1}$, M. V. Morozova ${ }^{1}$, Z. A. Mikhailovskaya ${ }^{1}$, O. S. Kaymieva ${ }^{1}$, V. M. Zhukovskiy 1 , S.A. Petrova ${ }^{2}$

${ }^{1}$ Ural Federal University, 620002 Ekaterinburg, Mira str., 19, tel: (343) 261-75-53 E-mail: elena.buyanova@urfu.ru

${ }^{2}$ Institute of metallurgy UB RAS, 620016 Ekaterinburg, Amundsen St., 101, tel: (343) 267-88-94

E-mail:danaus@mail.ru

\title{
Crystal structure and conductivity of bismuth-containing complex oxides
}

In the paper, a comprehensive systematic study of different classes of bismuth containing oxide compounds was carried out. The relationship between composition, temperature and concentration regions of existence of stable, specific structure and properties of solid solutions on the basis of vanadates, molybdates, niobates and bismuth was found. The general regularities of synthesis of solid solutions with different variants of solid-phase and soluble methods were determined. On this basis, the optimal conditions for obtaining single-phase materials were formulated. For the first time the temperature and concentration boundaries of the regions of homogeneity and areas of stable existence of polymorphic modifications of solid solutions were defined and/or refined. The structural parameters of the synthesized phases were determined. By the method of electrochemical impedance spectroscopy the nature and features of impedance spectra, the temperature and concentration dependences of electrical conductivity of ceramic materials based on bismuth containing complex oxides were identified.

Key words: method of electrochemical impedance spectroscopy; bismuth containing oxides; oxygen-ionic conductivity; thermocycling.

(C) Buyanova E. S., Emelyanova Yu. V., Morozova M. V., Mikhailovskaya Z. A., Kaymieva 0. S.,

Zhukovskiy V. M., Petrova S. A., 2015

\section{Introduction}

The complex oxides on the basis of $\mathrm{Bi}_{2} \mathrm{O}_{3}$ provide a vast class of objects of interest from the point of view of both fundamental and applied science. Among practically important physical and chemical properties can distinguish oxygen-ion 
and mixed conductivity in middle temperature region $\left(300-700{ }^{\circ} \mathrm{C}\right)$, ferroelectric and magnetic effects. Bismuth-containing compounds crystallize in different structure types to a greater extent crystal - or perovskite-like, including having a layered structure. Depending on the dimensionality of charge transfer process, the bismuth-containing complex oxides can be divided into 3 types: three-dimensional (family of complex oxides that is similar to $\delta-\mathrm{Bi}_{2} \mathrm{O}_{3}$ ); two-dimensional (BIMEVOX family); and one-dimensional, represented by phases on the basis of $\mathrm{Bi}_{26} \mathrm{Mo}_{10} \mathrm{O}_{69}$, containing column $\left[\mathrm{Bi}_{12} \mathrm{O}_{14}\right]_{\infty}$. An important feature of the compounds is

\section{The experimental part}

The series compounds of $\mathrm{Bi}_{4} \mathrm{~V}_{2-x} \mathrm{Me}_{x}$ $\mathrm{O}_{11-\delta}$ or BIMEVOX $(\mathrm{Me}=\mathrm{Cu}, \mathrm{Fe}, \mathrm{Ti}, \mathrm{Nb})$, $\mathrm{Bi}_{13} \mathrm{Mo}_{5-x} \mathrm{Me}_{x} \mathrm{O}_{34-\delta}$ and $\mathrm{Bi}_{13-x} \mathrm{Me}_{x} \mathrm{Mo}_{5} \mathrm{O}_{34+\delta}$, $(\mathrm{Me}=\mathrm{Mg}, \mathrm{Ca}, \mathrm{Sr}, \mathrm{Ba}, \mathrm{Co}, \mathrm{Fe}), \mathrm{Bi}_{6.95} \mathrm{Y}_{0.05} \mathrm{Nb}_{2-}$ ${ }_{y} \mathrm{Me}_{\mathrm{y}} \mathrm{O}_{15,5 \pm \delta}$ and $\mathrm{Bi}_{3} \mathrm{Nb}_{1-y} \mathrm{Me}_{y} \mathrm{O}_{7 \pm \delta}(\mathrm{Me}=\mathrm{Fe}$, $\mathrm{Zr}, \mathrm{W}$ ) were obtained by standard ceramic technology, or using different variants of synthesis of the mortar. The features of synthesis for each particular case are described in [1-15].

X-ray examination of samples was carried out using diffractometer DRON-3 (CuKa-radiation, monochromator of pyrolytic graphite on the reflected beam), D8 ADVANCE (CuKa-radiation, $\beta$-filter, position sensitive detector VÅNTEC, high-temperature chamber Anton Paar HTK $1200 N$ ). Analysis of the phase composition and calculation of the crystallographic parameters was carried out using the presence of the cation of bismuth $6 \mathrm{~s}^{2}$ lone-pair electrons, which leads to a high polarizability of the cationic sublattice. The stereochemical activity of the electron pair of bismuth ions is manifested in the ability to the formation of highly disordered oxygen environment of bismuth, change in symmetry of the coordination polyhedras and the way to ensure the dissociation of oxygen molecules.

This work presents the results of studies of bismuth-containing complex oxide compounds of different structural families, held at the Ural University in recent years.

DIFFRAC ${ }^{\text {plus }}$ EVA, Match-DEMO, Celref and databases PDF4+ ICDD, COD and AMCSD. Dilatometric analysis was performed using the dilatometer DIL $402 \mathrm{C}$ Netzsch with a vacuum-tight oven, differential thermal analysis was performed using thermoanalyzer STA 409 PC Luxx, Netzsch. Microscopic investigations were performed using scanning electronic (raster) microscope JEOL JSM 6390LA consoles and energy dispersive JEOL JED 2300. Elemental analysis of samples was performed by atomic emission spectroscopy with inductively coupled plasma and atomic absorption spectrometry on the spectrometer iCAP 6500 and M6 Solar Thermo Scientific. The total conductivity of the samples was measured by the method of impedance spectroscopy (impedancemetry Z-350M, Z-3000 firm "Elins").

\section{Results and discussion}

For all systems the processes of phase formation during their synthesis using a solid-phase, different versions of mortar methods, mechano-chemical activation were systematically investigated, the optimum conditions for obtaining single- 
phase compositions were found. The phase formation in the systems $\mathrm{Bi}_{2} \mathrm{O}_{3}$ $\mathrm{V}_{2} \mathrm{O}_{5}$-oxides $\mathrm{Cu}, \mathrm{Fe}, \mathrm{Ti}, \mathrm{Nb}$ is always in some series-parallel stages with formation of intermediate products of composition $\mathrm{Bi}_{1.33} \mathrm{~V}_{2} \mathrm{O}_{6}$ and $\mathrm{BiVO}_{4}$, vanadates of the respective metals, for example, $\mathrm{Cu}_{5} \mathrm{~V}_{2} \mathrm{O}_{10}$, $\mathrm{Fe}_{2} \mathrm{~V}_{4} \mathrm{O}_{13}$, mixed oxides of bismuth and related cations $\left(\mathrm{Bi}_{24} \mathrm{Ti}_{2} \mathrm{O}_{40}, \mathrm{Bi}_{20} \mathrm{TiO}_{32}, \mathrm{Bi}_{8} \mathrm{~N}\right.$ $\mathrm{b}_{18} \mathrm{O}_{57}$ ). It is established that the oxides of bismuth cations and the relevant cations the processes of formation of phases BIMEVOX in the synthesis using liquid precursors is generally similar to the processes of phase formation during solidphase synthesis. The vanadate bismuth of the composition $\mathrm{BiVO}_{4}$ is formed in all methods in the primary sludge. The interaction of the bismuth components with the formation of single-phase product in the field homogeneity during the synthesis phases BIMEVOX using liquid precursors ends at temperatures $100-150 \mathrm{~K}$ lower than during solid-phase synthesis. When using the mechano-chemical method, the samples composition $\mathrm{Bi}_{4} \mathrm{~V}_{2} \mathrm{O}_{11}$, $\mathrm{Bi}_{4} \mathrm{~V}_{1.7} \mathrm{Cu}_{0.15} \mathrm{Ti}_{0.15} \mathrm{O}_{11-\delta}, \mathrm{Bi}_{4} \mathrm{~V}_{1.8} \mathrm{Fe}_{0.2} \mathrm{O}_{11-\delta}$ were obtained only after annealing of the mechanically activated mixture at a temperature of $873 \mathrm{~K}$. Under the same conditions of mechano-chemical synthesis of singlephase $\mathrm{Bi}_{4} \mathrm{~V}_{1.4} \mathrm{Nb}_{0.6} \mathrm{O}_{11-\delta}$ was obtained after two minutes of activation. The phase formation by mechanical activation, as with other methods of synthesis goes through several series-parallel stages, which confirms the general complex nature of the interaction in the layered perovskite-like systems. However, at the final stage of the synthesis by any of the proposed options with appropriate concentrations of metal formed solid solutions belong to one of the possible polymorphic modifications of bismuth vanadate are formed [1-5].

The formation of solid solutions based on bismuth molybdate $\mathrm{Bi}_{13} \mathrm{Mo}_{5} \mathrm{O}_{34 \pm \delta}$ during the synthesis of solid-phase method goes through the stage of formation of intermediate compounds $\mathrm{Bi}_{38} \mathrm{Mo}_{7} \mathrm{O}_{78}$ and $\mathrm{Bi}_{2} \mathrm{MoO}_{6}$; complex oxides of bismuth and a metal dopant. In the synthesis using soluble reagents as impurities has a significant amount of $\alpha$-phase $\left(\mathrm{Bi}_{2} \mathrm{Mo}_{3} \mathrm{O}_{12}\right)$, a hydroxide of bismuth, $\mathrm{Bi}_{2} \mathrm{MoO}_{6}$. Analysis of reaction products after different stages of thermal processing has shown that in the case of the introduction in the process of synthesis procedures for the tempering of samples, the number and concentration of intermediates is significantly reduced, and single-phase final product forms at a temperature $1073-1123 \mathrm{~K}$. The structural features of the different structural families of complex oxides are investigated, the boundaries of the regions of homogeneity, structural parameters and concentration intervals of existence of polymorphic modifications are defined. The high-symmetry complex oxides are formed on the basis of $\delta-\mathrm{Bi}_{2} \mathrm{O}_{3}$ with the fluorite structure with the occupancy of the oxygen sublattice at about $75 \%$ (PR. gr. $F m-3 m$ ) with partial substitution of metal ions for other cations. In this case, the region of homogeneity of solid solutions has a small length, for example, for a series $\mathrm{Bi}_{3} \mathrm{Nb}_{1-y} \mathrm{Zr}_{y} \mathrm{O}_{7 \pm \delta}$ is the boundary located at $x=0.4$, the series $\mathrm{Bi}_{6.95} \mathrm{Y}_{0.05} \mathrm{Nb}_{2}$ $\mathrm{Zr}_{\mathrm{y}} \mathrm{O}_{15.5 \pm \delta}$ when $y=0.3$. For $\mathrm{Bi}_{6.95} \mathrm{Y}_{0.05} \mathrm{Nb}_{2}$ ${ }_{y} \mathrm{Fe}_{\mathrm{y}} \mathrm{O}_{15.5 \pm \delta}$ at a maximum temperature of $1073 \mathrm{~K}$ synthesis it is limited by the composition $y=0.2$.

Outside the homogeneity region, or when the temperature changes often there is a mixture of two phases pseudokoningii 
type $\mathrm{Bi}_{3} \mathrm{NbO}_{7}$ with close lattice parameters and different content of metals. At low concentrations of dopant the stabilization of the tetragonal modification of solid solutions is possible, for example, for $\mathrm{Bi}_{3} \mathrm{Nb}_{1-y} \mathrm{~W}_{y} \mathrm{O}_{7 \pm \delta}$ or $\mathrm{Bi}_{3} \mathrm{Nb}_{1-y} \mathrm{Fe}_{y} \mathrm{O}_{7 \pm \delta}$ $(y=0.1)$.

The existence regions of structural modifications phases BIMEVOX vary depending on the composition and less used method of synthesis. With a small content of operauser metal the solid solutions crystallize in the monoclinic (Pr. gr. $\mathrm{C} 2 / m)$ or orthorhombic ((Pr. gr. Aba2 или Amam) modification, by increasing the concentration of the dopant leads to the formation of tetragonal $\gamma$-modification. In the wide concentration interval of the tetragonal $\gamma$-modification (Pr. gr $14 / \mathrm{mmm}$ ) at room temperature is stable due to the substitution positions of vanadium to niobium $(0.30 \leq x \leq 0.90)$, iron $(0.20 \leq x \leq 0.50)$ and with a double substitution of iron and niobium $(0.2<$ $x<0.575) . \gamma$-modification BICUTIVOX at room temperature was obtained for compositions with $0.25 \leq x \leq 0.50$ only during rapid cooling (tempering) with the last stage of synthesis. The series of solid substitution solutions based on bismuth molybdate $\mathrm{Bi}_{13} \mathrm{Mo}_{5} \mathrm{O}_{34 \pm \delta}$ crystallize in triclinic and monoclinic modifications. In particular, the triclinic modification of (Pr. gr. P-1) forms by substitution in the sublattice of molybdenum and low concentrations of dopant for the series $\mathrm{Bi}_{13} \mathrm{Mo}_{5-y} \mathrm{Co}_{y} \mathrm{O}_{34 \pm \delta}(y \leq 0.05)$ or bismuth for $\mathrm{Bi}_{13-x} \mathrm{Mg}_{x} \mathrm{Mo}_{5} \mathrm{O}_{34 \pm \delta}(x \leq 0.1)$, $\mathrm{Bi}_{13-x} \mathrm{Ca}(\mathrm{Sr}, \quad \mathrm{Ba})_{x} \mathrm{Mo}_{5} \mathrm{O}_{34 \pm \delta}(x \leq 0.4)$, $\mathrm{Bi}_{13-x} \mathrm{Co}_{x} \mathrm{Mo}_{5} \mathrm{O}_{34 \pm \delta}(x \leq 0.05)$. Monoclinic modification (Pr. gr. P2/c) forms with the substitution in the sublattice of molybdenum compounds for $\mathrm{Bi}_{13} \mathrm{Mo}_{5-y} \mathrm{Co}_{y} \mathrm{O}_{34 \pm \delta}$ $(y \leq 0.2)$ or bismuth, for example, $\mathrm{Bi}_{13-x}$ $\mathrm{Mg}_{\mathrm{x}} \mathrm{Mo}_{5} \mathrm{O}_{34 \pm \delta}(x \leq 0.4), \mathrm{Bi}_{13-x} \mathrm{Ca}(\mathrm{Sr}, \mathrm{Ba})_{\mathrm{x}}$ $\mathrm{Mo}_{5} \mathrm{O}_{34 \pm \delta,}(x \leq 0.7), \quad \mathrm{Bi}_{13-x} \mathrm{Co}_{x} \mathrm{Mo}_{5} \mathrm{O}_{34 \pm \delta}$ $(x \leq 0.2)$. An $x$-ray when you change the symmetry of the unit cell for different structural types is shown in Fig. 1, an example of the dependence of unit cell parameters from the structure is shown in Fig. 2.

The regularities of the change of symmetry and the unit cell parameters of different polymorphic modifications of investigated series of samples depending on

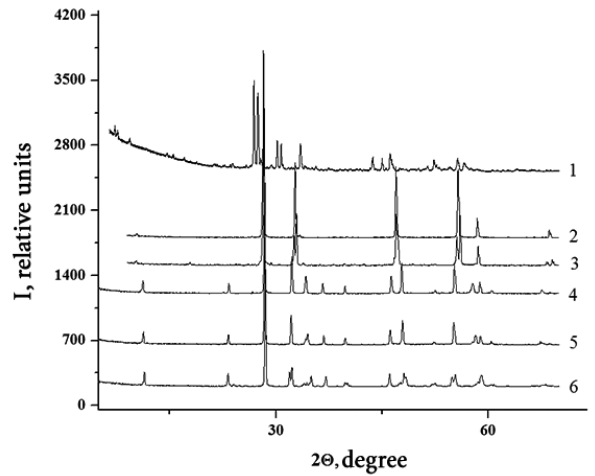

Fig. 1. Examples of radiographs of different structural types: : $1-\mathrm{Bi}_{12.9} \mathrm{Ba}_{0.1} \mathrm{Mo}_{5} \mathrm{O}_{34 \pm \delta}$ (Pr. gr. P-1) $2-\mathrm{Bi}_{3} \mathrm{Nb}_{0.8} \mathrm{~W}_{0.2} \mathrm{O}_{7 \pm \delta,}$ (Pr. gr.

$F m-3 m) ; 3-\mathrm{Bi}_{3} \mathrm{Nb}_{0.9} \mathrm{Fe}_{0.1} \mathrm{O}_{7 \pm \delta .}$ (Pr. gr. $I-4 m 2$ ); $4-\gamma$-BIMEVOX (Pr. gr. I4/mmm); 5 $\beta$-BIMEVOX (Pr. gr. Amam), 6 - $a$-BIMEVOX (Pr. gr. C2/m)

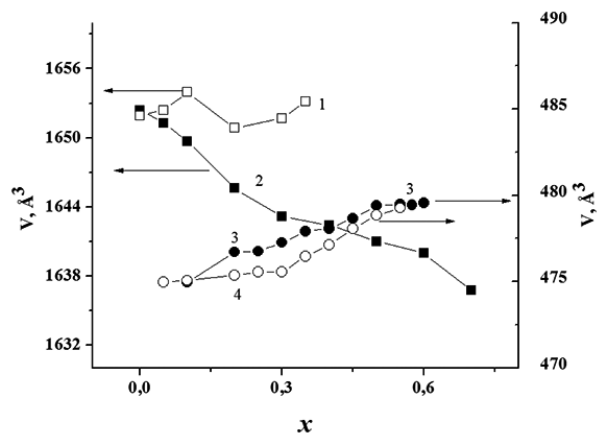

Fig. 2. The dependence of the volume of the unit cell composition: $1-\mathrm{Bi}_{13} \mathrm{Mo}_{5-y} \mathrm{Fe}_{y} \mathrm{O}_{34+\delta}$; $2-\mathrm{Bi}_{13-x} \mathrm{Ca}_{x} \mathrm{Mo}_{5} \mathrm{O}_{34 \pm \delta} ; 3-\mathrm{Bi}_{4} \mathrm{~V}_{2-\mathrm{x}} \mathrm{Fe}_{\mathrm{x} / 2} \mathrm{Nb}_{\mathrm{x} / 2} \mathrm{O}_{11-\delta}$; $4-\mathrm{Bi}_{4} \mathrm{~V}_{2-\mathrm{x}} \mathrm{Fe}_{\mathrm{x}} \mathrm{O}_{11-\delta}$ 
temperature were revealed. For example, for phases BIMEVOX family with increasing content of the dopant extends the temperature region of existence of the tetragonal $\gamma$-modification. The effect of the uneven change of parameters while maintaining the linearity of the change of unit cell volume with temperature for a series BICRFEVOX is found that is explained changes in vanadate layer structure.

The study of the crystal structure of tetragonal $\mathrm{Bi}_{4} \mathrm{~V}_{2-x} \mathrm{Fe}_{x} \mathrm{O}_{11-\delta}$ depending on temperature and oxygen partial pressure revealed a significant stability of this modification in a fairly wide range of thermodynamic parameters. The change in the structure of the tetragonal modification BIFEVOX in orthorhombic occurs in an environment with low oxygen content (at $\left.\operatorname{lgPo}{ }_{2}=-18.0(\mathrm{~atm}).\right)$ and at temperatures above $770 \mathrm{~K}$. The baric dependences of the volume of the unit cell $\mathrm{Bi}_{4} \mathrm{~V}_{1.7}, \mathrm{Fe}_{0.3} \mathrm{O}_{11-\delta}$ at different temperatures are shown in Fig.3. In addition, the samples of this series with $\mathrm{x}=0.3-0.4$ have the greatest stability under thermal cycling.

Using high-temperature $\mathrm{x}$-ray studied the thermal behavior of the series $\mathrm{Bi}_{13} \mathrm{Mo}_{5-x} \mathrm{Me}_{x} \mathrm{O}_{34-\delta}$ and $\mathrm{Bi}_{13-x} \mathrm{Me}_{x} \mathrm{Mo}_{5} \mathrm{O}_{34 \pm \delta}$

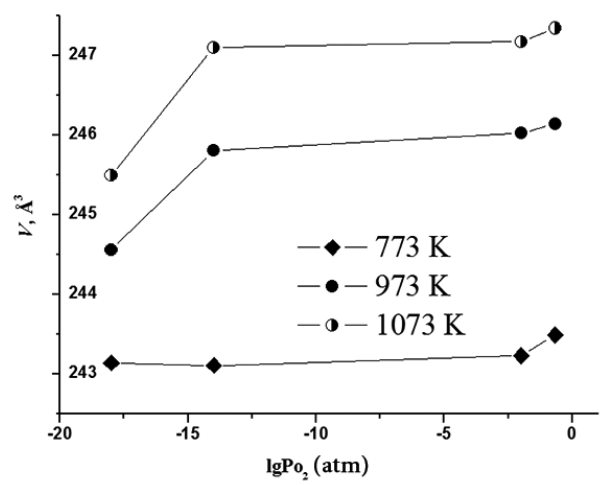

Fig. 3. The baric dependence of the volume of the unit cell $\mathrm{Bi}_{4} \mathrm{~V}_{1.7} \mathrm{Fe}_{0.3} \mathrm{O}_{11-\delta}$ at different temperatures with different dopants was studied. The changes of unit cell parameters in the phase transition from triclinic to monoclinic modification occurs abruptly and is accompanied by a small contraction of the unit cell. In the areas above and below the transition temperature the dependence is linear. However, at temperatures above $950 \mathrm{~K}$ there is a slight deviation from the linear behavior. An example of such dependencies for $\mathrm{Bi}_{13} \mathrm{Mo}_{4.9} \mathrm{Fe}_{0.1} \mathrm{O}_{34 \pm \delta}$, obtained according to $\mathrm{x}$-ray and neutron diffraction, are given in fig. 4. Most likely this is due to the change in the mechanism of interaction between columnar elements and/or disordered polyhedra of molybdenum-oxygen framework of the same symmetry.

With the increase in the concentration of the dopant the transition temperature from monoclinic to triclinic modification expected decreases: for example, with the composition $\mathrm{Bi}_{12.9} \mathrm{Ca}_{0.1} \mathrm{Mo}_{5} \mathrm{O}_{34 \pm \delta}$ the phase transition temperature was equal to $\sim 593 \mathrm{~K}$, for the composition $\mathrm{Bi}_{12.6} \mathrm{Ca}_{0.4} \mathrm{Mo}_{5} \mathrm{O}_{34 \pm \delta} \sim 523 \mathrm{~K}$.

The evaluation of the elemental composition of the investigated phases, taken in powder, or near the surface and in the

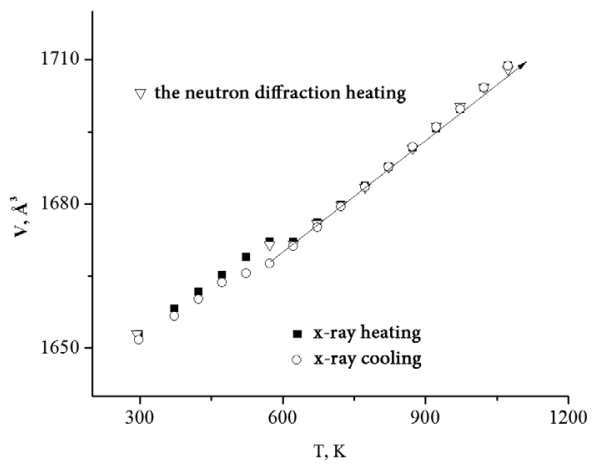

Fig. 4. The dependence of the volume of the unit cell $\mathrm{Bi}_{13} \mathrm{Mo}_{4.9} \mathrm{Fe}_{0.1} \mathrm{O}_{34 \pm \delta}$ on temperature according to neutron and $\mathrm{x}$-ray diffraction. The arrow shows a linear plot 
bulk sintered pellets by atomic spectroscopy, and electron microscopy revealed that is not always realized even distribution of atoms in the structures of the solid solutions. This necessitates not only the phase, but the element of local and general control elements content in them. For example, for the system BICUTIVOX regardless of the method of synthesis has been uneven joining of titanium atoms into the crystal lattice of the solid solution accompanied by the formation of uncontrolled trace impurities phases, enriched with titanium, which affects mechanical and electrical properties. Such effect is absent for BIFEVOX, BINBVOX. The uniform distribution of atoms in the structure is observed for all columnar series of molybdates of bismuth. For bismuth niobates with increasing concentration of the dopant is observed the formation of two structures pseudokoningii (let's denote them as $\delta$ and $\delta /$ ). For example, by the results of surface analysis and sample volume $\mathrm{Bi}_{6.95} \mathrm{Y}_{0.05} \mathrm{Nb}_{1.4} \mathrm{Zr}_{0.6} \mathrm{O}_{15.5 \pm \delta}$ single-phase slightly is saturated with bismuth, and the other is saturated with niobium. The composition of one phase is $\delta-\mathrm{Bi}_{3} \mathrm{Nb}_{0.72} \mathrm{Zr}_{0.28} \mathrm{O}_{7-\delta}$, and the second is $\delta^{\prime}-\mathrm{Bi}_{1.7} \mathrm{Nb}_{0.23} \mathrm{Zr}_{0.07} \mathrm{O}_{3.30-\delta}$. The coefficients of thermal expansion of both phases are close, the only difference between them is in the area $973-1073 \mathrm{~K}$, where the phase $\delta /$ is observed an anomaly of the unit cell parameters associated with the beginning of the collapse. According to the RFA above $973 \mathrm{~K}$ we observe the emergence of phase $\mathrm{Bi}_{12} \mathrm{Nb}_{0.29} \mathrm{O}_{18.7+x}$ and a simultaneous decrease of the intensities of the reflexes of the phase $\delta /$.

For all series of samples the processes of non-isothermal sintering of ceramic briquettes were investigated that are allowed to establish their characteristics and the optimal values of the temperature-time characteristics of sintering. The samples were characterized by density, sintering, porosity, values of linear coefficients of thermal expansion. The highest value for LCTR phases BIMEVOX is $\sim 20 \times 10^{-6} \mathrm{~K}^{-1}$ and is characteristic of high-temperature $\gamma$-modification at low concentrations of dopant. For columnar of molybdates of bismuth it is a bit lower, $14-16 \times 10^{-6} \mathrm{~K}^{-1}$. Thus, unlike phases BIMEVOX, size LCTR for triclinic and monoclinic modifications are close, therefore, a sharp change in their volume during the phase transition does not occur, which is beneficial to the mechanical properties of the ceramic briquettes. The average values for LCTR bismuth niobates are in the area of $11.7 \times 10^{-6}-11.8 \times 10^{-6} \mathrm{~K}^{-1}$.

By the method of electrochemical impedance spectroscopy identified the nature and features of impedance spectra, the temperature and concentration dependences of electrical conductivity of ceramic materials of all investigated series of samples were identified. The hodographs of the impedance of the studied compounds have the typical form of polycrystalline ionic conductors, and are composed of two or more combined semicircles, corresponding to the total resistance of the sample, the electrode and diffusion processes. The example of impedance diagram is shown in Fig. 5. The corresponding equivalent circuit is based on a block-layered model that includes as mandatory elements of the impedance and the frequency-dependent component (examples in Fig. 6).

The course of temperature dependences of electrical conductivity is consistent with the concentration intervals of exis- 


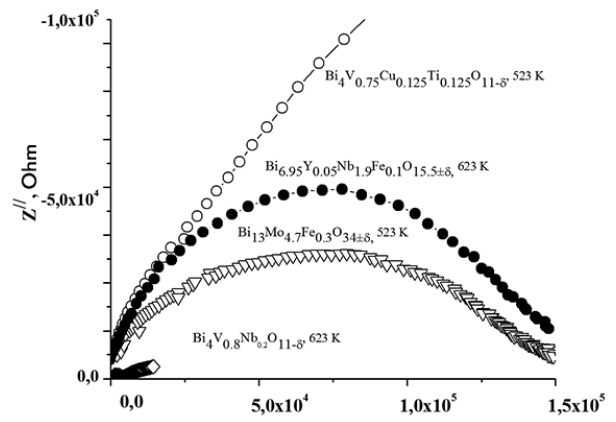

Fig. 5. Impedance diagrams for different compounds

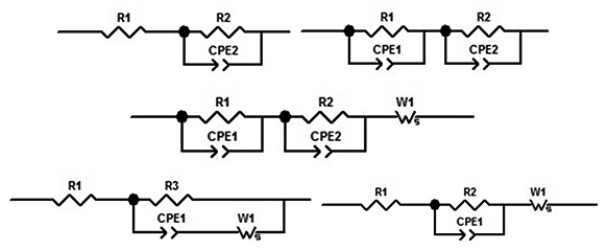

Fig. 6. Examples of equivalent circuits used for analysis of impedance

tence of structural modifications: in the presence of phase transitions within the interval on politermo reflect the changes in the slope of the dependencie. For example, for phases BIMEVOX at low concentrations of dopant (for example, $x=$ $0.05)$, typical observed $\gamma \rightarrow \beta(853 \mathrm{~K})$ and $\beta \rightarrow a(723 \mathrm{~K})$ of successive phase transitions corresponding to the change of structure $(\mathrm{I} / \mathrm{mmm} \rightarrow$ Amam $\rightarrow \mathrm{C} 2 / \mathrm{m})$ and is characterized by the change of activation energy of conductivity of solid solutions. For $\gamma$-modification phases BIMEVOX solid solutions the values of activation energies at high temperatures are characteristic of the magnitude of $0.2-0.4 \mathrm{eV}$. The transition into an ordered $\gamma /$-modification with decreasing temperature is accompanied by a change of the tilt according to $\lg \sigma-10^{3} / \mathrm{T}$ and the increase of the activation energy to $0.5-0.7 \mathrm{eV}$. The electrical conductivity of ceramics made from powders obtained by the methods of synthesis using liquid precursors, is in average by 0.5 orders of magnitude higher compared with ceramics of the same composition obtained by a solid phase method. Investigation of electrical conductivity of some compositions of the solid solution BIFEVOX, BINBVOX depending on the partial pressure of oxygen showed that this dependence has a linear character, indicating a predominant oxygen-ion conductivity of this type of solid solutions.

On the temperature dependence of conductivity of solid solutions on the basis of $\mathrm{Bi}_{13} \mathrm{Mo}_{5} \mathrm{O}_{34 \pm \delta}$ are dedicated three ranges, characterized by different values of activation energy of conductivity: lowtemperature is inherent triclinic form $\mathrm{E}_{\text {акт }}$ $(\mathrm{HT})=0.9-1.3 \mathrm{eV}$; medium - and hightemperature $\left(\left(\mathrm{E}_{\text {акт }}(\mathrm{BT})=0.5-0.6\right.\right.$ эB; $\mathrm{E}_{\text {акт }}(\mathrm{CT})=0.65-0.8 \ni \mathrm{B}$ is inherent to the monoclinic form. On the example of the samples of molybdates of bismuth-doped iron it is shown that the change in conductivity of materials in high-temperature and medium-temperature interval is correlated with changes in the oxygen sublattice of compounds within the life of the monoclinic modification, namely, due to the disordering of the oxygen polyhedra and the emergence of structure in the solid solution of the conjugate Mo-O of trigonal bipyramid.

For bismuth niobates the temperature dependence of electrical conductivity are linear, as determined by the absence of phase transitions in solid solutions of these compounds. The value of activation energy of conductivity is an average value of $0.9-1.1 \mathrm{eV}$. The highest conductivity have samples with a high concentration of phase $\delta /$, which is a solid solution based on the highly conductive $\delta$-modification 
of bismuth oxide. Examples of the dependences are shown in Fig. 7.

The dependence of the conductivity on the concentration of the dopant usually has a parabolic type with a maximum at small concentrations of the dopant, which

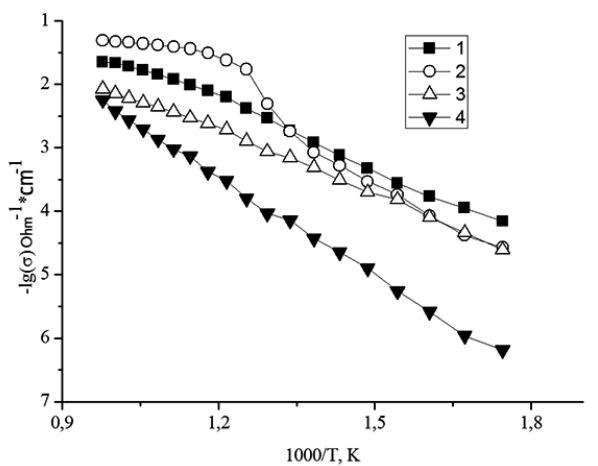

Fig. 7. Temperature dependence of conductivity of complex oxides:

$1-\mathrm{Bi}_{4} \mathrm{~V}_{1.75} \mathrm{Fe}_{0.125} \mathrm{Nb}_{0.125} \mathrm{O}_{11-\delta} ; 2-$

$\mathrm{Bi}_{4} \mathrm{~V}_{1.9} \mathrm{Fe}_{0.1} \mathrm{O}_{11-\delta} ; 3-\mathrm{Bi}_{12.8} \mathrm{Ba}_{0.2} \mathrm{Mo}_{5} \mathrm{O}_{34 \pm \delta} ; 4-$ $\mathrm{Bi}_{6.95} \mathrm{Y}_{0.05} \mathrm{Nb}_{1.7} \mathrm{Fe}_{0.3} \mathrm{O}_{15.5 \pm \delta}$

is typical for many oxide systems (Fig. 8) and can be determined by the interaction of defects, or any structural factors. For example, the columnar bismuth molybdates the maximum value of conductivity is typical for the «transition state»: the area of occurrence of monoclinic or triclinic modifications modifications in the parameters is close to monoclinic.
According to the results of the executed complex studies you can identify the most promising formulations from the viewpoint of conductive properties and stability under conditions of operation at elevated temperatures and variation of

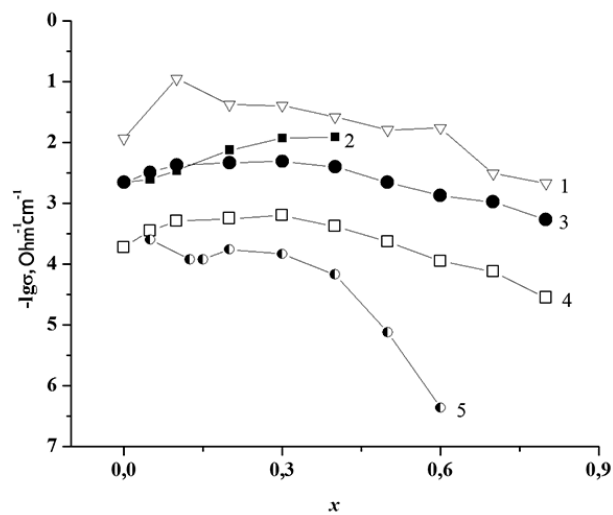

Fig. 8. The dependence of the conductivity of complex oxides on: 1 - BINBVOX, $1023 \mathrm{~K} ; 2-\mathrm{Bi}_{13} \mathrm{Mo}_{5-\mathrm{y}} \mathrm{Fe}_{\mathrm{y}} \mathrm{O}_{34 \pm \delta} ; 1023 \mathrm{~K}$; $3-\mathrm{Bi}_{13-\mathrm{x}} \mathrm{Ca}_{\mathrm{x}} \mathrm{Mo}_{5} \mathrm{O}_{34+\delta}, 1023 \mathrm{~K} ; 4-\mathrm{Bi}_{13-\mathrm{x}}$ $\mathrm{Ca}_{\mathrm{x}} \mathrm{Mo}_{5} \mathrm{O}_{34 \pm \delta}, 723 \mathrm{~K} ; 5$ - BIFEVOX, $673 \mathrm{~K}$

thermodynamic parameters. It is series of solid solutions BIFEVOX, BINBVOX, BIFENBVOX with a dopant concentration of 25-30 mol. \% substituted columnar bismuth molybdate compositions $\mathrm{Bi}_{12.8} \mathrm{Ba}_{0.2} \mathrm{Mo}_{5} \mathrm{O}_{34 \pm \delta}$ и $\mathrm{Bi}_{13} \mathrm{Mo}_{4.7} \mathrm{Fe}_{0.3} \mathrm{O}_{34 \pm \delta}$.

1. Emel'yanova Yu. V., Shafigina R. R., Buyanova E. S., Zhukovskii V. M., Zainullina V. M., Petrova S. A. Oxide Ion Conductors of the BIMEVOX Family: Synthesis, Structure, and Conductivity. Russian Journal of Physical Chemistry. 2006;80(11):1725-1730. doi: $10.1134 /$ S0036024406110057

2. Zhukovskii V. M., Emel'yanova Yu. V., Shafigina R. R., Petrova S. A., Zainullina V. M., Buyanova E. S. Oxide Ceramics BIMEVOX: Conductivity, Structure, and Chemical Bond. Russian Journal of Electrochemistry. 2007;43(4):443-447. doi: 10.1134/ S1023193507040118

3. Zhukovskii V. M., Buyanova E. S., Emel'yanova Yu. V., Morozova M. V., Shafigina R. R., Zakharov R. G., Zhuravlev V. D. Synthesis, Structure, and Conductivity of BIME- 
VOX Oxide Ceramics. Russian Journal of Electrochemistry. 2009;45(5):512-519. doi: 10.1134/S1023193509050024.

4. Buyanova E. S., Petrova S. A., Emel'yanova Yu. V., Blinova A. L., Morozova M. V., Zhukovskii V. M., Zhuravlev V. D. Preparation, Structure, and Charge Transport Characteristics of BIFEVOX Ultrafine Powders. Russian Journal of Inorganic Chemistry. 2009;54(8):1193-1204. doi: 10.1134/S0036023609080051.

5. Buyanova E. S., Petrova S. A., Emel'yanova Yu. V., Borodina N. A., Zakharov R. G., Zhukovskii V. M. Crystal Structure and Conduction of BICUTIVOX. Russian Journal of Inorganic Chemistry. 2009;54(6):864-872. doi: 10.1134/S0036023609060084

6. Morozova M. V., Buyanova E. S., Petrova S. A., Khisametdinova V. V., Emel'yanova Yu. V., Shatokhina A. N., Zhukovskii V.M. Structural and Thermal Stability of BIMEVOX Oxygen Semiconductors. Russian Journal of Electrochemistry. 2011;47(4):448-452. doi: 10.1134/S1023193511040100

7. Morozova M. V., Buyanova E. S., Emelyanova Yu. V., Zhukovskiy V. M., Petrova S. A. Highconducting oxide ceramics BIMEVOX: synthesis, structure, properties. Solid State Ionics. 2011;192:153-157. doi: 10.1016/j.ssi.2010.04.020

8. Morozova M. V., Buyanova E. S., Emelyanova Ju. V., Zhukovskiy V. M., Petrova S. A., Zakharov R. G., Tarakina N. V. Specific features in the synthesis, crystal structure and electrical conductivity of BICUTIVOX. Solid State Ionics. 2011;201:27-34. doi: 10.1016/j.ssi.2011.07.010

9.BuyanovaE.S.,ShafiginaR.R., MorozovaM.V.,Emel'yanova Yu.V., KhisametdinovaV.V., Zhukovskii V. M., Petrova S. A., Tarakina N. V. Electrochemical Characteristics, Thermal and Chemical Compatibility in the $\mathrm{La}_{0.7} \mathrm{Sr}_{0.3} \mathrm{CoO}_{3}$ Electrode- $\gamma$-BIFEVOX Electrolyte System. Russian Journal of Inorganic Chemistry. 2013;58(5):554-558. doi: 10.1134/S0036023613050033.

10. Kaymieva O. S., Tarasova O. A., Shatokhina A. N., Buyanova E. S., Morozova M. V., Zhukovskii V. M. Structural and Transport Characteristics of Substituted Bismuth Niobates. Russian Journal of Electrochemistry. 2013;49(7):652-657. doi: 10.1134/ S1023193513070057.

11. Mikhailovskaya Z. A., Buyanova E. S., Petrova S. A., Zhukovskiy V. M. Oxygen-Ionic Conductors Based on Substituted Bismuth Molybdates with Column-Type Structural Fragments. Russian Journal of Electrochemistry. 2013;49(7):658-664. doi:10.1134/ S1023193513070112.

12. Buyanova E. S., Morozova M. V., Emelyanova Yu. V., Petrova S.A., Zakharov R. G., Tarakina N. V., Zhukovskiy V. M. Structure, thermal stability and electrical conductivity of BINBVOX. Solid State Ionics. 2013;243:8-17. doi: 10.1016/j.ssi.2013.04.009.

13. Mikhailovskaya Z. A., Buyanova E. S., Petrova S. A., Morozova M. V., Zhukovskiy V. M., Zakharov R.G., Tarakina N. V., Berger I. F. Cobalt-doped $\mathrm{Bi}_{26} \mathrm{Mo}_{10} \mathrm{O}_{69}$ : crystal structure and conductivity. Journal of Solid State Chemistry. 2013;204:9-15. doi: 10.1016/j.jssc.2013.05.006.

14. Buyanova E. S., Petrova S. A., Mikhailovskaya Z. A., Kaymieva O. S., Shatokhina A. N., Emelyanova Yu. V., Morozova M. V. Synthesis, Structure, and Conductivity 
of Substituted Bismuth Niobate $\mathrm{Bi}_{7} \mathrm{Nb}_{2} \mathrm{O}_{15.5}$. Russian Journal of Inorganic Chemistry. 2015;60(8):913-920. doi: 10.1134/S0036023615080045.

15. Mikhaylovskaya Z. A., Buyanova E. S., Morozova M. V., Petrova S. A., Zakharov R. G., Nikolaenko I. V., Abrahams I. $\mathrm{Bi}_{13-\mathrm{x}} \mathrm{Me}_{\mathrm{x}} \mathrm{Mo}_{5} \mathrm{O}_{34 \pm \delta}(\mathrm{Me}=\mathrm{Mg}, \mathrm{Ca}, \mathrm{Sr}, \mathrm{Ba})$ solid solutions: synthesis and properties. Ionics. 2015;21(8):2259-2268. doi: 10.1007/ s11581-015-1421-3. 
Е. С. Буянова, ${ }^{1}$ Ю. В. Емельянова, ${ }^{1}$ М. В. Морозова, ${ }^{1}$ 3. А. Михайловская, ${ }^{1}$ О. С. Каймиева, ${ }^{1}{ }^{1}$. М. Жуковский, ${ }^{1}$ С. А. Петрова ${ }^{2}$

${ }^{1}$ Уральский федеральный университет, 620002 Екатеринбург, ул. Мира, 19, тел: (343) 261-75-53

E-mail: elena.buyanova@urfu.ru

${ }^{2}$ Институт металлургии УрО РАН, 620016 Екатеринбург, ул. Амундсена, 101, тел: (343) 267-88-94

E-mail:danaus@mail.ru

\section{Кристаллическая структура и проводимость висмут-содержащих сложных оксидов}

В работе выполнено комплексное систематическое исследование различных классов висмут-содержащих оксидных соединений. Найдена взаимосвязь состава, температурных и концентрационных областей устойчивого существования, специфики структуры и свойств твердых растворов на основе ванадатов, молибдатов, ниобатов висмута. Установлены общие закономерности синтеза твердых растворов с использованием различных вариантов твердофазного и растворных методов. На этой основе сформулированы оптимальные условия получения однофазных материалов. Определены впервые и/или уточнены температурные и концентрационные границы областей гомогенности и областей устойчивого существования полиморфных модификаций твердых растворов. Установлены структурные параметры синтезированных фаз. Методом спектроскопии электрохимического импеданса выявлены характер и особенности импедансных спектров, температурных и концентрационных зависимостей электропроводности керамических материалов на основе висмутсодержащих сложных оксидов.

Ключевые слова: метод спектроскопии электрохимического импеданса; висмутсодержащие оксиды; кислородно-ионная проводимость; термоциклирование.

(c) Буянова Е. С., Емельянова Ю. В., Морозова М. В., Михайловская З. А., Каймиева О. С., Жуковский В. М., Петрова С. А., 2015

\section{Введение}

Сложные оксиды на основе $\mathrm{Bi}_{2} \mathrm{O}_{3}$ дают обширный класс объектов, представляющих интерес с точки зрения как фундаментальной, так и прикладной науки. Среди практически значимых физико-химических свойств

можно выделить кислородно-ионную и смешанную проводимость в средней области температур $\left(300-700{ }^{\circ} \mathrm{C}\right)$, сегнетоэлектрические и магнитные эффекты. Висмут-содержащие соединения кристаллизуются в различных 
типах структур, в большей степени, флюорито- или перовскитоподобных, в том числе имеющих слоистое строение. В зависимости от мерности процесса переноса заряда висмут-содержащие сложные оксиды можно разделить на три типа: трехмерные (семейство сложных оксидов, подобных $\delta$ - $\mathrm{Bi}_{2} \mathrm{O}_{3}$ ); двумерные (семейство BIMEVOX) и одномерные, представленные фазами на основе $\mathrm{Bi}_{26} \mathrm{Mo}_{10} \mathrm{O}_{69}$ ' содержащими колонки $\left[\mathrm{Bi}_{12} \mathrm{O}_{14}\right]_{\infty}$. Важной особенностью соединений является наличие у катиона висмута неподеленной $6 s^{2}$ пары электронов, что приводит к высокой поляризуемости катионной подрешетки. Стереохимическая активность электронной пары ионов висмута проявляется в способности к образованию высоко разупорядоченного кислородного окружения висмута, изменению симметрии координационных полиэдров и возможности обеспечивать диссоциацию молекул кислорода. В настоящей работе представлены результаты исследований висмут-содержащих сложнооксидных соединений различных структурных семейств, проведенных в Уральском университете за последние годы.

\section{Экспериментальная часть}

Соединения серий $\mathrm{Bi}_{4} \mathrm{~V}_{2-x} \mathrm{Me}_{x} \mathrm{O}_{11-\delta}$ или BIMEVOX $(\mathrm{Me}=\mathrm{Cu}, \mathrm{Fe}, \mathrm{Ti}, \mathrm{Nb})$, $\mathrm{Bi}_{13} \mathrm{Mo}_{5-x} \mathrm{Me}_{x} \mathrm{O}_{34-\delta}$ и $\mathrm{Bi}_{13-x} \mathrm{Me}_{x} \mathrm{Mo}_{5} \mathrm{O}_{34 \pm \delta}$ $(\mathrm{Me}=\mathrm{Mg}, \mathrm{Ca}, \mathrm{Sr}, \mathrm{Ba}, \mathrm{Co}, \mathrm{Fe})$, $\mathrm{Bi}_{6,95} \mathrm{Y}_{0,05} \mathrm{Nb}_{2-y} \mathrm{Me}_{y} \mathrm{O}_{15,5 \pm \delta}$ и $\mathrm{Bi}_{3} \mathrm{Nb}_{1-y} \mathrm{Me}_{y} \mathrm{O}_{7 \pm \delta}$ $(\mathrm{Me}=\mathrm{Fe}, \mathrm{Zr}, \mathrm{W})$ получены либо по стандартной керамической технологии, либо с использованием различных вариантов растворного синтеза. Особенности синтеза для каждого конкретного случая описаны в [1-15].

Рентгеновские исследования образцов проводили с использованием дифрактометров ДРОН-3 (CuK $K_{\alpha}$-излучение, монохроматор из пиролитического графита на отраженном пучке), D8 ADVANCE (CuK излучение, $\beta$-фильтр, позиционночувствительный детектор VÅNTEC, высокотемпературная камера Anton Paar HTK 1200N). Анализ фазового состава и расчет кристаллографических параметров осуществляли с использованием программных пакетов
DIFFRAC ${ }^{\text {plus }}$ EVA, Match-DEMO, Celref и баз данных PDF4+ ICDD, COD и AMCSD. Дилатометрический анализ выполнен с помощью дилатометра DIL 402 C Netzsch с вакуум-плотной печью, дифференциальный термический анализ - с использованием термоанализатора STA 409 PC Luxx, Netzsch. Микроскопические исследования проведены с помощью сканирующего электронного (растрового) микроскопа JEOL JSM 6390LA и энергодисперсионной приставки JEOL JED 2300. Элементный анализ образцов выполняли методом атомно-эмиссионной спектроскопии с индуктивно связанной плазмой и атомно-абсорбционной спектроскопии на спектрометрах iCAP 6500 и Solar M6 Thermo Scientific. Общую электропроводность образцов измеряли методом импедансной спектроскопии (импедансметры Z-350M, Z-3000 фирмы «Elins»). 


\section{Результаты и обсуждение}

Для всех систем систематически исследованы процессы фазообразования при их синтезе с использованием твердофазного, различных вариантов растворного методов, механохимической активации, найдены оптимальные условия получения однофазных составов. Фазообразование в системax $\mathrm{Bi}_{2} \mathrm{O}_{3}-\mathrm{V}_{2} \mathrm{O}_{5}$-оксиды $\mathrm{Cu}, \mathrm{Fe}, \mathrm{Ti}, \mathrm{Nb}$ всегда идет в несколько последовательно-параллельных стадий с образованием промежуточных продуктов состава $\mathrm{Bi}_{1,33} \mathrm{~V}_{2} \mathrm{O}_{6}$ и $\mathrm{BiVO}_{4}$, ванадатов соответствующих металлов, например, $\mathrm{Cu}_{5} \mathrm{~V}_{2} \mathrm{O}_{10}, \mathrm{Fe}_{2} \mathrm{~V}_{4} \mathrm{O}_{13}$, сложных оксидов висмута и соответствующих катионов $\left(\mathrm{Bi}_{24} \mathrm{Ti}_{2} \mathrm{O}_{40}, \mathrm{Bi}_{20} \mathrm{TiO}_{32}, \mathrm{Bi}_{8} \mathrm{Nb}_{18} \mathrm{O}_{57}\right)$. Установлено, что процессы формирования BIMEVOX при синтезе через жидкие прекурсоры в целом аналогичны процессам фазообразования при твердофазном синтезе. Во всех методах в первичном осадке образуется ванадат висмута состава $\mathrm{BiVO}_{4}$. Взаимодействие компонентов с образованием однофазного продукта в области гомогенности при синтезе BIMEVOX с использованием жидких прекурсоров заканчивается при температуре на 100-150 К ниже, чем при твердофазном синтезе. При использовании механохимического метода образцы состава $\mathrm{Bi}_{4} \mathrm{~V}_{2} \mathrm{O}_{11}, \mathrm{Bi}_{4} \mathrm{~V}_{1,7} \mathrm{Cu}_{0,15} \mathrm{Ti}_{0,15} \mathrm{O}_{11-\delta}$, $\mathrm{Bi}_{4} \mathrm{~V}_{1,8} \mathrm{Fe}_{0,2} \mathrm{O}_{11-\delta}$ получены только после отжига механоактивированной смеси при температуре 873 К. При тех же условиях механохимического синтеза однофазный $\mathrm{Bi}_{4} \mathrm{~V}_{1,4} \mathrm{Nb}_{0,6} \mathrm{O}_{11-\delta}$ получен уже после двух минут активации. Фазообразование при механоактивации, как и при использовании других методов синтеза, идет через несколько по- следовательно-параллельных стадий, что подтверждает общий сложный характер взаимодействия в слоистых перовскитоподобных системах. Тем не менее на конечном этапе синтеза любым из предложенных вариантов при соответствующих концентрациях металла образуются твердые растворы, относящиеся к одной из возможных полиморфных модификаций ванадата висмута [1-5].

Образование твердых растворов на основе молибдата висмута $\mathrm{Bi}_{13} \mathrm{Mo}_{5} \mathrm{O}_{34 \pm \delta}$ при синтезе твердофазным методом идет через стадии формирования промежуточных соединений $\mathrm{Bi}_{38} \mathrm{Mo}_{7} \mathrm{O}_{78}$ и $\mathrm{Bi}_{2} \mathrm{MoO}_{6}$; сложных оксидов висмута и металла-допанта. При синтезе с использованием растворимых реагентов в качестве примесей присутствует значительное количество $\alpha$-фазы $\left(\mathrm{Bi}_{2} \mathrm{Mo}_{3} \mathrm{O}_{12}\right)$, гидроксид висмута, $\mathrm{Bi}_{2} \mathrm{MoO}_{6}$. Анализ продуктов реакции после различных стадий температурной обработки показал, что в случае введения в процесс синтеза процедуры закаливания образцов количество и концентрация промежуточных соединений значительно уменьшаются, и конечный однофазный продукт образуется при температуре 1073-1123 К.

Исследованы структурные особенности различных структурных семейств сложных оксидов, определены границы областей гомогенности, структурные параметры и концентрационные интервалы существования полиморфных модификаций. Высокосимметричные сложные оксиды образуются на основе $\delta$ - $\mathrm{Bi}_{2} \mathrm{O}_{3}$, имеющего структуру флюорита с заселенностью по подрешетке кисло- 
рода около 75 \% (пр. гр. Fm-3m) при замещении части ионов металла на другие катионы. При этом область гомогенности твердых растворов имеет небольшую протяженность, например, для серии $\mathrm{Bi}_{3} \mathrm{Nb}_{1-y} \mathrm{Zr}_{y} \mathrm{O}_{7 \pm \delta}$ ее граница находится при $x=0,4$, серии $\mathrm{Bi}_{6,95} \mathrm{Y}_{0,05} \mathrm{Nb}_{2-y} \mathrm{Zr}_{y} \mathrm{O}_{15,5 \pm \delta}-$ при $y=0,3$. Для $\mathrm{Bi}_{6,95} \mathrm{Y}_{0,05} \mathrm{Nb}_{2-y} \mathrm{Fe}_{y} \mathrm{O}_{15,5 \pm \delta}$ при максимальной температуре синтеза $1073 \mathrm{~K}$ она ограничена составом $y=0,2$. За пределами области гомогенности или при изменении температуры часто наблюдается смесь двух псевдокубических фаз типа $\mathrm{Bi}_{3} \mathrm{NbO}_{7}$ с близкими параметрами элементарной ячейки и различным содержанием металлов. При малых концентрациях допанта возможна стабилизация тетрагональной модификации твердых растворов, например, для $\mathrm{Bi}_{3} \mathrm{Nb}_{1-y} \mathrm{~W}_{y} \mathrm{O}_{7 \pm \delta}$ или $\mathrm{Bi}_{3} \mathrm{Nb}_{1-y} \mathrm{Fe}_{y} \mathrm{O}_{7 \pm \delta}(y=0.1)$.

Области существования структурных модификаций BIMEVOX различаются в зависимости от состава и в меньшей степени - использованного метода синтеза. При небольшом содержании допирующего металла твердые растворы кристаллизуются в моноклинной (пр. гр. $C 2 / m$ ) или орторомбической (пр. гр. Aba2 или Amam) модификации, при увеличении концентрации допанта происходит образование тетрагональной $\gamma$-модификации. В наиболее широком концентрационном интервале тетрагональная $\gamma$-модификация (пр. гр $I 4 / \mathrm{mmm}$ ) при комнатной температуре стабилизирована за счет замещения позиций ванадия на ниобий $(0,30 \leq x \leq 0,90)$, железо $(0,20 \leq x \leq 0,50)$, а также при двойном замещении на железо и ниобий $(0,2<x$ $<0,575) . \gamma$-Модификация BICUTIVOX при комнатной температуре получена для составов с $0,25 \leq x \leq 0,50$ только при быстром охлаждении (закаливании) с последней стадии синтеза.

Серии твердых растворов замещения на основе молибдата висмута $\mathrm{Bi}_{13} \mathrm{Mo}_{5} \mathrm{O}_{34 \pm \delta}$ кристаллизуются в триклинной и моноклинной модификациях. В частности, триклинная модификация (пр. гр. P-1) образуется при замещении в подрешетку молибдена и малых концентрациях допанта для серии $\mathrm{Bi}_{13} \mathrm{Mo}_{5-y} \mathrm{Co}_{y} \mathrm{O}_{34 \pm \delta}(y \leq 0,05)$ или висмута для $\mathrm{Bi}_{13-x} \mathrm{Mg}_{x} \mathrm{Mo}_{5} \mathrm{O}_{34 \pm \delta}(x \leq 0,1)$, $\mathrm{Bi}_{13-x} \mathrm{Ca}(\mathrm{Sr}, \mathrm{Ba})_{x} \mathrm{Mo}_{5} \mathrm{O}_{34 \pm \delta}(x \leq 0,4)$, $\mathrm{Bi}_{13-x} \mathrm{Co}_{x} \mathrm{Mo}_{5} \mathrm{O}_{34 \pm \delta}(x \leq 0,05)$. Моноклинная модификация (пр. гр. Р2/c) при замещении в подрешетку молибдена для составов $\mathrm{Bi}_{13} \mathrm{Mo}_{5-y} \mathrm{Co}_{y} \mathrm{O}_{34 \pm \delta}$ $(y \leq 0,2)$ или висмута, например, $\mathrm{Bi}_{13-x}$ $\mathrm{Mg}_{x} \mathrm{Mo}_{5} \mathrm{O}_{34 \pm \delta}(x \leq 0,4), \mathrm{Bi}_{13-x} \mathrm{Ca}(\mathrm{Sr}, \mathrm{Ba})_{x}$ $\mathrm{Mo}_{5} \mathrm{O}_{34 \pm \delta,}(x \leq 0,7), \quad \mathrm{Bi}_{13-x} \mathrm{Co}_{x} \mathrm{Mo}_{5} \mathrm{O}_{34 \pm \delta}$ $(x \leq 0,2)$. Изменение вида рентгенограмм при изменении симметрии элементарной ячейки для различных структурных типов приведено на рис. 1, пример зависимости параметров элементарной ячейки от состава - на рис. 2.

Выявлены закономерности изменения симметрии и параметров элементарной ячейки различных полиморфных модификаций исследованных серий образцов в зависимости от температуры. Например, для семейства BIMEVOX при увеличении содержания допанта расширяется температурная область существования тетрагональной $\gamma$-модификации. Обнаружен эффект неравномерного изменения параметров при сохранении линейности изменения объема элементарной ячейки с температурой для серии 
BICRFEVOX, что объяснено изменениями в ванадатном слое структуры.

Исследование кристаллической структуры тетрагонального $\mathrm{Bi}_{4} \mathrm{~V}_{2-x}$ $\mathrm{Fe}_{x} \mathrm{O}_{11-\delta}$ в зависимости от температуры и парциального давления кислорода выявило значительную устойчивость данной модификации в достаточно широком интервале термодинамических параметров. Изменение структуры тетрагональной модификации BIFEVOX в орторомбическую происходит в среде с низким содержанием кислорода (при $\lg \mathrm{PO}_{2}=-18,0$ (атм.)) и при температуре выше 770 К. Барические зависимости объема элементарной ячейки $\mathrm{Bi}_{4} \mathrm{~V}_{1,7} \mathrm{Fe}_{0,3} \mathrm{O}_{11-\delta}$ при различных температурах приведены на рис. 3. Кроме того, образцы этой серии при $x=0,3-0,4$ обладают наибольшей устойчивостью при термоциклировании.

Методом высокотемпературной рентгенографии изучено термическое поведение серий $\mathrm{Bi}_{13} \mathrm{Mo}_{5-x} \mathrm{Me}_{x} \mathrm{O}_{34-\delta}$ и $\mathrm{Bi}_{13-x} \mathrm{Me}_{x} \mathrm{Mo}_{5} \mathrm{O}_{34 \pm \delta}$ с различными до-

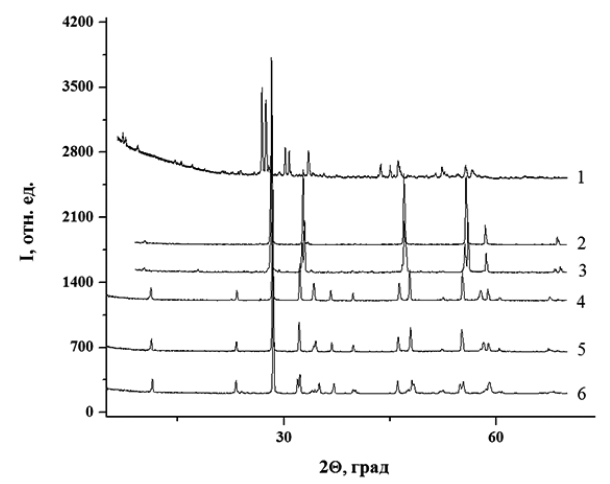

Рис. 1. Примеры рентгенограмм различных структурных типов: $1-\mathrm{Bi}_{1,9} \mathrm{Ba}_{0,1} \mathrm{Mo}_{5} \mathrm{O}_{34 \pm \delta,}$ (пр. гр. P-1) $2-\mathrm{Bi}_{3} \mathrm{Nb}_{0,8} \mathrm{~W}_{0,2} \mathrm{O}_{7 \pm \delta}$, $3-\mathrm{Bi}_{3} \mathrm{Nb}_{0,9} \mathrm{Fe}_{0,1} \mathrm{O}_{7 \pm \delta}$ (пр. гр. I-4m2); 4 - $\gamma$-BIMEVOX (пр. гр. $I 4 / \mathrm{mmm}$ ), 5 - $\beta$-BIMEVOX (Пр. гр. Amam), 6 a-BIMEVOX (пр. гр. C2/m) пантами. Изменения параметров элементарной ячейки в области фазового перехода из триклинной в моноклинную модификацию происходят скачкообразно, сопровождаясь небольшим сжатием элементарной ячейки. В областях выше и ниже температуры перехода зависимости линейны. Однако при температуре выше $950 \mathrm{~K}$ наблюдается небольшое отклонение от линейного хода. Пример подобной зависимости для $\mathrm{Bi}_{13} \mathrm{Mo}_{4,9} \mathrm{Fe}_{0,1} \mathrm{O}_{34 \pm \delta}$, полученной по данным рентгеновской и нейтронной дифракции, приведен на рис. 4.

Вероятнее всего, это связано с изменением механизма взаимодействия колончатых элементов и/или разупорядоченных полиэдров молибден-кислород в рамках одной симметрии.

С повышением концентрации допанта температура перехода из триклинной в моноклинную модификацию ожидаемо снижается: например, для состава $\mathrm{Bi}_{12,9} \mathrm{Ca}_{0,1} \mathrm{Mo}_{5} \mathrm{O}_{34 \pm \delta}$ температура фазового перехода составила $\sim 593 \mathrm{~K}$, для состава $\mathrm{Bi}_{12,6} \mathrm{Ca}_{0,4} \mathrm{Mo}_{5} \mathrm{O}_{34 \pm \delta}-$ $\sim 523 \mathrm{~K}$.

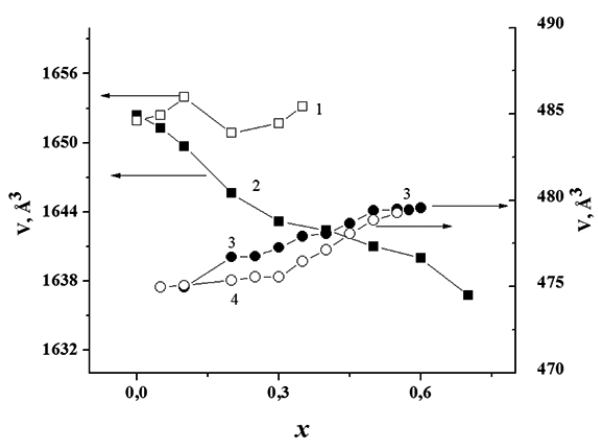

Рис. 2. Зависимость объема элементарной ячейки от состава: $1-\mathrm{Bi}_{13} \mathrm{Mo}_{5-y} \mathrm{Fe}_{y} \mathrm{O}_{34 \pm \delta}$; $2-\mathrm{Bi}_{13-x} \mathrm{Ca}_{x} \mathrm{Mo}_{5} \mathrm{O}_{34 \pm \delta ;} 3-\mathrm{Bi}_{4} \mathrm{~V}_{2-x} \mathrm{Fe}_{x / 2} \mathrm{Nb}_{x / 2} \mathrm{O}_{11-\delta ;}$ $4-\mathrm{Bi}_{4} \mathrm{~V}_{2-x} \mathrm{Fe}_{x} \mathrm{O}_{11-\delta}$ 
Оценка элементного состава исследуемых фаз, взятых в виде порошка, либо вблизи поверхности и в объеме спеченных брикетов методами атомной спектроскопии и электронной микроскопии выявила, что не всегда реализуется равномерное распределение атомов в структурах твердых растворов. Это вызывает необходимость не только фазового, но элементного локального и общего контроля содержания элементов в них. Например, для системы BICUTIVOX независимо от метода синтеза наблюдается неравномерное вхождение атомов титана в кристаллическую решетку твердого раствора, сопровождающееся образованием неконтролируемых микропримесей фаз, обогащенных титаном, что сказывается на механических и электропроводящих свойствах. Подобный эффект отсутствует для BIFEVOX, BINBVOX. Равномерное распределение атомов в структуре наблюдается для всех серий колончатых молибдатов висмута. Для ниобатов висмута при росте концентрации допанта наблюдается образование двух псевдо-

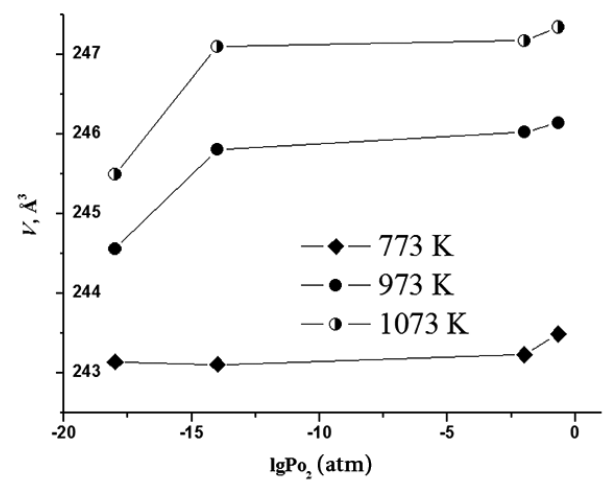

Рис. 3. Барические зависимости объема элементарной ячейки $\mathrm{Bi}_{4} \mathrm{~V}_{1,7} \mathrm{Fe}_{0,3} \mathrm{O}_{11-\delta}$ при различных температурах кубических структур (обозначим их как $\delta$ и $\delta^{\prime}$ ). Например, по результатам анализа поверхности и объема образца $\mathrm{Bi}_{6,95} \mathrm{Y}_{0,05} \mathrm{Nb}_{1,4} \mathrm{Zr}_{0,6} \mathrm{O}_{15,5 \pm \delta}$ одна фаза незначительно насыщена висмутом, а другая - ниобием. Состав одной фазы - $\delta-\mathrm{Bi}_{3} \mathrm{Nb}_{0,72} \mathrm{Zr}_{0,28} \mathrm{O}_{7-\delta}$, а второй $\delta^{\prime}-\mathrm{Bi}_{1,7} \mathrm{Nb}_{0,23} \mathrm{Zr}_{0,07} \mathrm{O}_{3,30-\delta}$. Коэффициенты термического расширения обеих фаз близки, единственным отличием между ними является область 973-1073 К, в которой для фазы $\delta^{\prime}$ наблюдается аномалия параметров элементарной ячейки, связанная с началом распада. По данным РФА выше 973 К наблюдается появление фазы $\mathrm{Bi}_{12} \mathrm{Nb}_{0,29} \mathrm{O}_{18,7+\mathrm{x}}$ и одновременное падение интенсивностей рефлексов фазы $\delta$.

Для всех серий образцов исследованы процессы неизотермического спекания керамических брикетов, что позволило установить их особенности и оптимальные значения температурно-временных характеристик спекания. Образцы охарактеризованы по плотности спекания, пористости, значениям линейных коэффициентов термического расширения. Наибольшее

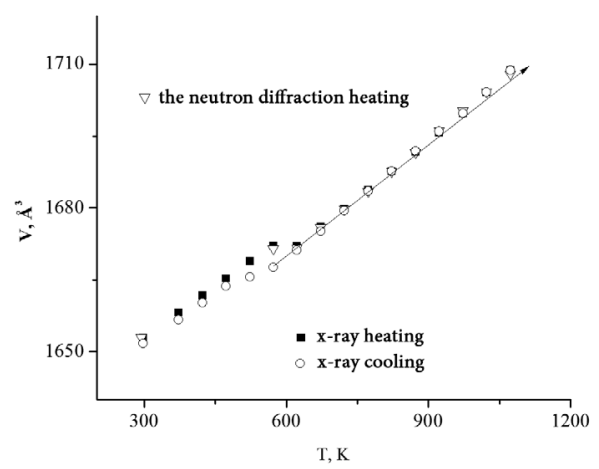

Рис. 4. Зависимость объема элементарной ячейки $\mathrm{Bi}_{13} \mathrm{Mo}_{4,9} \mathrm{Fe}_{0,1} \mathrm{O}_{34 \pm \delta}$ от температуры по данным нейтронной и рентгеновской дифракции. Стрелкой показан линейный участок 
значение ЛКТР для BIMEVOX составляет $20 \times 10^{-6} \mathrm{~K}^{-1}$ и характерно для высокотемпературной $\gamma$-модификации при низких концентрациях допанта. Для колончатых молибдатов висмута оно немного ниже и равно $14-16 \times 10^{-6} \mathrm{~K}^{-1}$. При этом, в отличие от BIMEVOX, величины ЛКТР для триклинной и моноклинной модификаций близки, следовательно, резкого изменения их объема при фазовом переходе не происходит, что благоприятно сказывается на механических свойствах керамических брикетов. Средние значения ЛКТР для ниобатов висмута находятся в области $11,7 \times 10^{-6}-11,8 \times 10^{-6} \mathrm{~K}^{-1}$.

Методом спектроскопии электрохимического импеданса выявлены характер и особенности импедансных спектров, температурных и концентрационных зависимостей электропроводности керамических материалов всех исследованных серий образцов. Годографы импеданса исследованных соединений имеют вид, типичный для поликристаллических ионных проводников, и состоят из двух или более сочетающихся полуокружностей, отвечающих общему сопротивлению образца, электродным и диффузионным процессам. Пример импедансной диаграммы приведен на рис. 5. Соответствующие эквивалентные схемы основаны на блочно-слоистой модели, включающей как обязательные элементы сопротивление и частотнозависимую компоненту (примеры на рис. 6).

Ход температурных зависимостей электропроводности согласуется с концентрационными интервалами существования структурных модификаций: при наличии фазовых перехо- дов внутри интервала на политермах фиксируются изменения наклона зависимостей. Например, для BIMEVOX при малых концентрациях допанта (например, $x=0,05)$, наблюдаются типичные $\gamma \rightarrow \beta(853 \mathrm{~K})$ и $\beta \rightarrow \alpha(723 \mathrm{~K})$ последовательные фазовые переходы, отвечающие смене структуры $(I 4 / \mathrm{mmm} \rightarrow$ Amam $\rightarrow C 2 / \mathrm{m})$ и характеризующиеся изменением энергии активации проводимости твердых растворов. Для $\gamma$-модификации твердых растворов BIMEVOX значения энергии активации при высоких температуpax составляют характерную величину 0,2-0,4 эВ. Переход в упорядоченную $\gamma^{\prime}$-модификацию при понижении температуры сопровождается сменой наклона зависимости $\lg \sigma-10^{3} / T$ и повышением энергии активации до 0,50,7 эВ. Электропроводность керамики,

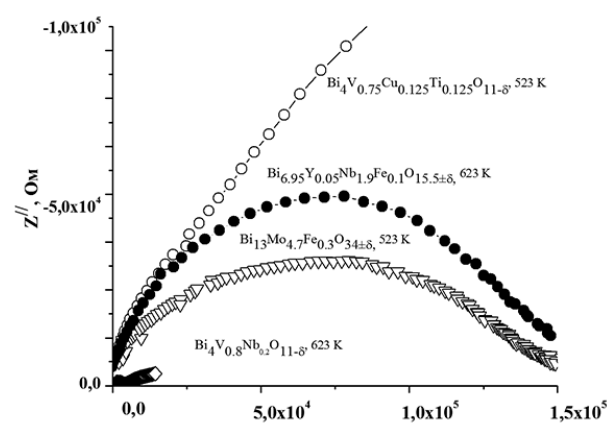

Рис. 5. Импедансные диаграммы для различных соединений
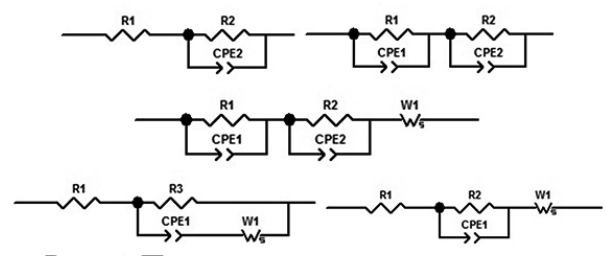

Рис. 6. Примеры эквивалентных схем, используемых при анализе импедансных диаграмм 
изготовленной из порошков, полученных методами синтеза через жидкие прекурсоры, в среднем на 0,5 порядка выше по сравнению с керамикой того же состава, полученной твердофазным методом. Исследование электропроводности некоторых составов твердых растворов BIFEVOX, BINBVOX в зависимости от парциального давления кислорода показало, что зависимость носит прямолинейный характер, что свидетельствует о преимущественной кислородно-ионной проводимости данного типа твердых растворов.

На температурных зависимостях электропроводности твердых растворов на основе $\mathrm{Bi}_{13} \mathrm{Mo}_{5} \mathrm{O}_{34 \pm \delta}$ выделены три диапазона, характеризующиеся различными значениями энергии активации проводимости: низкотемпературный, присущий триклинной форме $\mathrm{E}_{\text {акт }}(\mathrm{HT})=0,9-1,3$ эВ; средне- и высокотемпературный $\left(\mathrm{E}_{\text {акт }}(\mathrm{BT})=0,5-\right.$ 0,6 эВ; $\mathrm{E}_{\text {акт }}(\mathrm{CT})=0,65-0,8$ эВ), присущие моноклинной форме. На примере образцов молибдатов висмута, допированных железом, показано, что изменение проводимости материалов в высокотемпературном и среднетемпературном интервале соотносится с изменениями в кислородной подрешетке соединений в рамках существования моноклинной модификации, а именно, обусловлено разупорядочением кислородных полиэдров и появлением в структуре твердого раствора сопряженных Мо-О тригональных бипирамид.

Для ниобатов висмута температурные зависимости электропроводности имеют прямолинейный вид, что определяется отсутствием фазовых переходов у твердых растворов этих составов.
Значение энергии активации проводимости составляет в среднем величину 0,9-1,1 эВ. При этом наибольшей проводимостью обладают образцы с высокой концентрацией фазы $\delta^{\prime}$, являющейся твердым раствором на основе высокопроводящей $\delta$-модификации оксида висмута. Примеры зависимостей приведены на рис. 7.

Зависимость электропроводности от концентрации допанта чаще всего имеет параболический вид с максимумом при небольших концентрациях допанта, что характерно для многих оксидных систем (рис. 8) и может определяться взаимодействием дефектов либо какими-либо структурными факторами. Например, для колончатых молибдатов висмута максимальное значение проводимости характерно для «переходного состояния»: области появления моноклинной модификации или триклинной модификации, близкой по параметрам к моноклинной.

По результатам выполненных комплексных исследований можно выде-

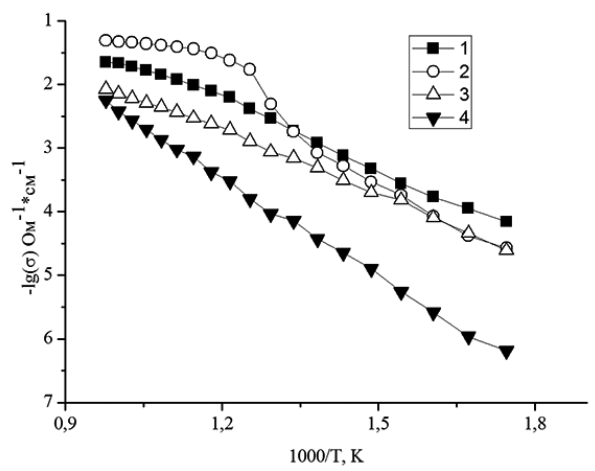

Рис. 7. Температурные зависимости проводимости сложных оксидов:

$$
1-\mathrm{Bi}_{4} \mathrm{~V}_{1,75} \mathrm{Fe}_{0,125} \mathrm{Nb}_{0,125} \mathrm{O}_{11-\delta} ; 2-
$$

$\mathrm{Bi}_{4} \mathrm{~V}_{1,9} \mathrm{Fe}_{0.1} \mathrm{O}_{11-\delta} ; 3-\mathrm{Bi}_{12,8} \mathrm{Ba}_{0,2} \mathrm{Mo}_{5} \mathrm{O}_{34 \pm \delta} ; 4-$ $\mathrm{Bi}_{6,95} \mathrm{Y}_{0,05} \mathrm{Nb}_{1,7} \mathrm{Fe}_{0,3} \mathrm{O}_{15,5 \pm \delta}$ 


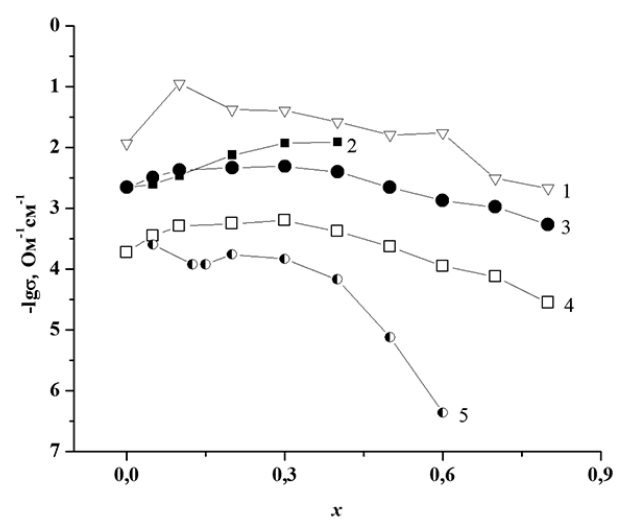

Рис. 8. Зависимость электропроводности сложных оксидов от температуры:

1 - BINBVOX, $1023 \mathrm{~K} ; 2$ - $\mathrm{Bi}_{13} \mathrm{Mo}_{5-y} \mathrm{Fe}_{y} \mathrm{O}_{34 \pm \delta}$, $1023 \mathrm{~K} ; 3-\mathrm{Bi}_{13-x} \mathrm{Ca}_{x} \mathrm{Mo}_{5} \mathrm{O}_{34 \pm \delta}, 1023 \mathrm{~K}$;

$4-\mathrm{Bi}_{13-x} \mathrm{Ca}_{x} \mathrm{Mo}_{5} \mathrm{O}_{34 \pm \delta}, 723 \mathrm{~K}$; 5 - BIFEVOX, $673 \mathrm{~K}$ лить наиболее перспективные составы с точки зрения электропроводящих свойств и устойчивости в условиях работы при повышенных температурах и варьировании термодинамических параметров. Это серии твердых растворов BIFEVOX, BINBVOX, BIFENBVOX с концентрацией допанта 25-30 мол. \%, замещенные колончатые молибдаты висмута составов $\mathrm{Bi}_{12,8} \mathrm{Ba}_{0,2} \mathrm{Mo}_{5} \mathrm{O}_{34 \pm \delta}$ и $\mathrm{Bi}_{13} \mathrm{Mo}_{4,7} \mathrm{Fe}_{0,3} \mathrm{O}_{34 \pm \delta}$.

1. Emel'yanova Yu. V., Shafigina R. R., Buyanova E. S., Zhukovskii V. M., Zainullina V. M., Petrova S. A. Oxide Ion Conductors of the BIMEVOX Family: Synthesis, Structure, and Conductivity. Russian Journal of Physical Chemistry. 2006;80(11):1725-1730. doi: 10.1134/S0036024406110057.

2. Zhukovskii V. M., Emel'yanova Yu. V., Shafigina R. R., Petrova S. A., Zainullina V. M., Buyanova E. S. Oxide Ceramics BIMEVOX: Conductivity, Structure, and Chemical Bond. Russian Journal of Electrochemistry. 2007;43(4):443-447. doi: 10.1134/ S1023193507040118.

3. Zhukovskii V. M., Buyanova E. S., Emel'yanova Yu. V., Morozova M. V., Shafigina R. R., Zakharov R. G., Zhuravlev V. D. Synthesis, Structure, and Conductivity of BIMEVOX Oxide Ceramics. Russian Journal of Electrochemistry. 2009;45(5):512519. doi: 10.1134/S1023193509050024.

4. Buyanova E. S., Petrova S. A., Emel'yanova Yu. V., Blinova A. L., Morozova M. V., Zhukovskii V. M., Zhuravlev V. D. Preparation, Structure, and Charge Transport Characteristics of BIFEVOX Ultrafine Powders. Russian Journal of Inorganic Chemistry. 2009;54(8):1193-1204. doi: 10.1134/S0036023609080051.

5. Buyanova E. S., Petrova S. A., Emel'yanova Yu. V., Borodina N. A., Zakharov R. G., Zhukovskii V. M. Crystal Structure and Conduction of BICUTIVOX. Russian Journal of Inorganic Chemistry. 2009;54(6):864-872. doi: 10.1134/S0036023609060084.

6. Morozova M. V., Buyanova E. S., Petrova S. A., Khisametdinova V. V., Emel'yanova Yu. V., Shatokhina A. N., Zhukovskii V.M. Structural and Thermal Stability of BIMEVOX Oxygen Semiconductors. Russian Journal of Electrochemistry. 2011;47(4):448-452. doi: $10.1134 /$ S1023193511040100. 
7. Morozova M. V., Buyanova E. S., Emelyanova Yu. V., Zhukovskiy V. M., Petrova S. A. High-conducting oxide ceramics BIMEVOX: synthesis, structure, properties. Solid State Ionics. 2011;192:153-157. doi: 10.1016/j.ssi.2010.04.020.

8. Morozova M. V., Buyanova E. S., Emelyanova Yu. V., Zhukovskiy V. M., Petrova S. A., Zakharov R. G., Tarakina N. V. Specific features in the synthesis, crystal structure and electrical conductivity of BICUTIVOX. Solid State Ionics. 2011;201:27-34. doi: 10.1016/j.ssi.2011.07.010.

9.BuyanovaE.S.,ShafiginaR.R.,MorozovaM.V.,Emel'yanova Yu. V., Khisametdinova V.V., Zhukovskii V. M., Petrova S. A., Tarakina N. V. Electrochemical Characteristics, Thermal and Chemical Compatibility in the $\mathrm{La}_{0.7} \mathrm{Sr}_{0.3} \mathrm{CoO}_{3}$ Electrode- $\gamma$-BIFEVOX Electrolyte System. Russian Journal of Inorganic Chemistry. 2013;58(5):554-558. doi: 10.1134/S0036023613050033.

10. Kaymieva O. S., Tarasova O. A., Shatokhina A. N., Buyanova E. S., Morozova M. V., Zhukovskii V. M. Structural and Transport Characteristics of Substituted Bismuth Niobates. Russian Journal of Electrochemistry. 2013;49(7):652-657. doi: 10.1134/ S1023193513070057.

11. Mikhailovskaya Z. A., Buyanova E. S., Petrova S. A., Zhukovskiy V. M. OxygenIonic Conductors Based on Substituted Bismuth Molybdates with Column-Type Structural Fragments. Russian Journal of Electrochemistry. 2013;49(7):658-664. doi: 10.1134/S1023193513070112.

12. Buyanova E. S., Morozova M. V., Emelyanova Yu. V., Petrova S.A., Zakharov R. G., Tarakina N.V.,Zhukovskiy V.M.Structure, thermal stability and electrical conductivity of BINBVOX. Solid State Ionics. 2013;243:8-17. doi: 10.1016/j.ssi.2013.04.009.

13. Mikhailovskaya Z. A., Buyanova E. S., Petrova S. A., Morozova M. V., Zhukovskiy V. M., Zakharov R.G., Tarakina N. V., Berger I. F. Cobalt-doped $\mathrm{Bi}_{26} \mathrm{Mo}_{10} \mathrm{O}_{69}$ : crystal structure and conductivity. Journal of Solid State Chemistry. 2013;204:9-15. doi: 10.1016/j.jssc.2013.05.006.

14. Buyanova E. S., Petrova S. A., Mikhailovskaya Z. A., Kaymieva O. S., Shatokhina A. N., Emelyanova Yu. V., Morozova M. V. Synthesis, Structure, and Conductivity of Substituted Bismuth Niobate $\mathrm{Bi}_{7} \mathrm{Nb}_{2} \mathrm{O}_{15.5}$. Russian Journal of Inorganic Chemistry. 2015;60(8):913-920. doi: 10.1134/S0036023615080045.

15. Mikhaylovskaya Z. A., Buyanova E. S., Morozova M. V., Petrova S. A., Zakharov R. G., Nikolaenko I. V., Abrahams I. Bi ${ }_{13-x} \mathrm{Me}_{x} \mathrm{Mo}_{5} \mathrm{O}_{34 \pm \delta}(\mathrm{Me}=\mathrm{Mg}, \mathrm{Ca}, \mathrm{Sr}, \mathrm{Ba})$ solid solutions: synthesis and properties. Ionics. 2015;21(8):2259-2268. doi: 10.1007/s11581-015$1421-3$. 